\title{
Persistent colonization of Helicobacter pylori in human gut induces gastroduodenal diseases
}

\author{
Animesh Sarker ${ }^{1}$, Tasnim Ahmed², Marufa Nasreen¹, Rafiad Islam¹, Rezual Islam³, Noor Jahan¹ \\ ${ }^{1}$ Department of Biotechnology and Genetic Engineering, University of Mawlana Bhashani Science and Technology. \\ Santosh, Tangail-1902.Bangladesh. \\ 2 Department of Genetic Engineering \& Bioechnology, University of Dhaka. Dhaka-1000, Bangladesh. \\ ${ }^{3}$ Department of Biochemistry and Molecular Biology, University of Dhaka, Dhaka-1000, Bangladesh.
}

\begin{abstract}
Helicobacter pylori are gut bacteria colonize in the epithelial cell lining of the stomach and persist there for long duration. Around two-thirds of the world's populations are infected with $H$. pylori and cause more than 90 percent of ulcers. The development of persistent inflammation is the main cause of chronic gastritis that finally results in a severe consequence known as stomach cancer. Two major virulence factors cytotoxin-associated gene product (cagA) and the vacuolating toxin (vacA) are mostly investigated as their close association with gastric carcinoma. In this review, host immunity against $H$. pylori infection and their evasion mechanism are intensely explored. It is the fact, that understanding pin point molecular mechanisms of any infection is critical to develop novel strategies to prevent pertinent diseases. $J$ Microbiol Infect Dis 2014; 4(4): 170-176
\end{abstract}

Key words: vacA, cagA, miRNA, COX-2, Gastric carcinoma

\section{İnsan barsağında gastrodüedonal hastalıklara yol açan Heliccobacter pylori'nin kalıcı kolonizasyonu}

\section{ÖZET}

Helicobacter pylori midenin epitelyal hücre hattında kolonize olan bir barsak bakterisi olup burada uzun süre sebat eder. Dünya nüfusunun yaklaşık üçte ikisi $H$. pylori ile enfektedir ve ülserlerin \% 90'ından fazlasının etkenidir. Devamlı enflamasyonun gelişmesi kronik gastritin başlıca sebebidir ve nihai olarak mide kanseri olarak bilinen ciddi sonuçlara yol açabilir. Mide karsinomu ile yakından ilişkili olan sitokine eşlik eden gen ürünü (cagA) ve vakuoleştirici toksin (vacA) en fazla araştırılan iki major virulans faktörüdür. Bu derlemede $H$. pylori'ye karşı konak immünitesi ve onların kurtulma mekanizmaları yoğun şekilde açıklandı. Gerçektende bir enfeksiyonun bağlanmasındaki moleküler mekanizmasını anlamak korunma için yeni stratejiler geliştirmede kritik öneme sahiptir.

Anahtar Kelimeler: vacA, cagA, miRNA, COX-2, Mide karsinomu

\section{INTRODUCTION}

Helicobacter pylori, (H. pylori), is a spiral-shaped bacterium residing in the mucus layer of human stomach. H. pylori secrete the enzyme urease to survive in the highly acidic condition of the stomach, as it converts urea to ammonia. Ammonia reduces the acidity, making bacteria friendly stomach environment. In addition, the helical shape of $H$. pylori allows it to dig into the mucus layer, which is less acidic than the inner area, or lumen, of the stomach. $H$. pylori can also stick to the cells that line up the inner surface of the stomach. Immune cells accumulate near sites of $H$. pylori infection in order to kill invading bacteria. They cannot prevent stomach lining erosion caused by the bacterium. Additionally, H. pylori interfere with local immune responses, making them unsuccessful in eliminating the bacteria. ${ }^{1,2}$

\section{Host-pathogen interaction}

The entire $H$. pylori genome consists of $\sim 1.65$ million nucleotide and encodes about one and half

Correspondence: Animesh Sarker, Department of Biotechnology and Genetic Engineering, Mawlana Bhashani Science and Technology University, Santosh, Tangail-1902.Bangladesh Email: animesh_du_geb@yahoo.com 
thousand proteins. ${ }^{3}$ The discovery of a large family of 32 associated outer-membrane proteins (Hop proteins) and the discovery of many genes that can be regulated by slipped strand mispairing-mediated mutagenesis were the most significant findings of two $H$. pylori genome-sequencing projects. ${ }^{4}$ Such phase-variable genes encode enzymes that alter the antigenic structure of surface molecules, support the entrance of foreign DNA into the bacteria, and accelerate bacterial motility. ${ }^{5}$ During persistent or transient mixed infections, $H$. pylori modifies its genome continuously by importing small pieces of foreign DNA from other $H$. pylori. ${ }^{6}$

Most of the $H$. pylori strains use an auto transporter mechanism to express the vacuolating cytotoxin VacA (95-kD), a secreted exotoxin.7,8 The toxin undergoes self-insertion into epithelial-cell membrane forming a hexameric anion-selective and voltage dependent channel through which bicarbonate and organic anions can be transported, providing nutrients to the bacterium. ${ }^{9,10}$ VacA also causes release of cytochrome $\mathrm{c}$ from mitochondrial membrane inducing apoptosis. ${ }^{11}$
Most of the VacA localizes on epithelial cell membrane and oligomerizes constructingan anion specific channels across the membrane. Overall impact of functional VacA on epithelial cells comprises modification of delayed endocytic cubicle, magnifying membrane permeability, and finally augmentation of apoptosis. ${ }^{12}$ Since S2 was found well conserved with VacA as it must have similar function which is still undefined. ${ }^{13,14}$

Mostly, $H$. pylori strains have the cag pathogenicity island (cag PAI), a 37-kb genomic portion containing 29 genes (Figure 1). The cagA (cytotoxinassociated gene $A$ ) gene is the most widely studied of all $H$. pylori genes. ${ }^{15,16}$ The $3^{\prime}$ region of the cagA gene is variable that is responsible for increased risk for gastric cancer and greater susceptibility to $\mathrm{pH}$. Several of these express constituents of a predicted type IV secretion apparatus that translocates the CagA protein $(120-k D)$ into the host cell. ${ }^{17}$ The cagA gene flanks $40 \mathrm{~kb}$ genomic region having 41 putative genes of the cag pathogenicity island (PAI) in $H$. pylori. These genes have remarkable role in increase of inflammation and secretion of virulencerelated products, like IL-8; recruitment of neutrophil, phosphorylation of tyrosine, and release of protein. ${ }^{18}$

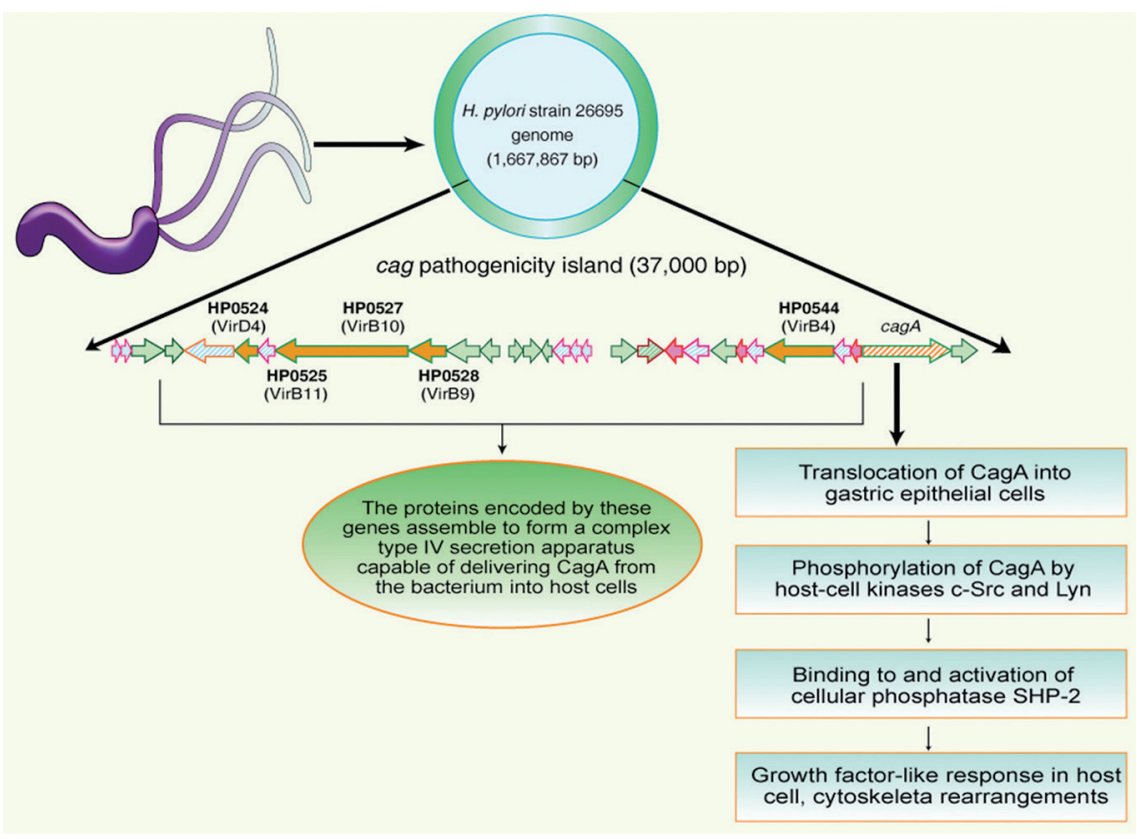

Figure 1. Structure and function of Cag pathogenecity island. This island spans for a 37,000 bp chromosomal region and includes twenty nine genes. The protein encoded by this island not only stimulate IL-8 production by gastric epithelial cells but also assisttranslocation of CagA into the host cell. The genes resposible for IL-8 production are indicated by solid arrows.And, the blue lined arrows indicates genes which form a type IV secretion apparatus that make a channel for CagA traffiicing. Additionally, orange lines indicates other virulence genes involved in pahogenesis.

H. pylori strains are varies with OMPs expression and adhesins properties. One of the outer membrane protein OipA $(\mathrm{HopH})$ also express differentially due to phase variation, which result in strain spesific signaling in gastric epithelial cells. ${ }^{22}$ Moreover multiple factor e.g. CagA+, s1-VacA+,
$\mathrm{BabA}+$ are found to be lofty interactive with the host, whereas strains that lacking these factors are under interactive (Figure 2). These CagA, s1-VacA, and BabA positive strains increases gastric mucosal inflammation and gastric epithelial injury, compared with other strains. ${ }^{23,24,25}$ 


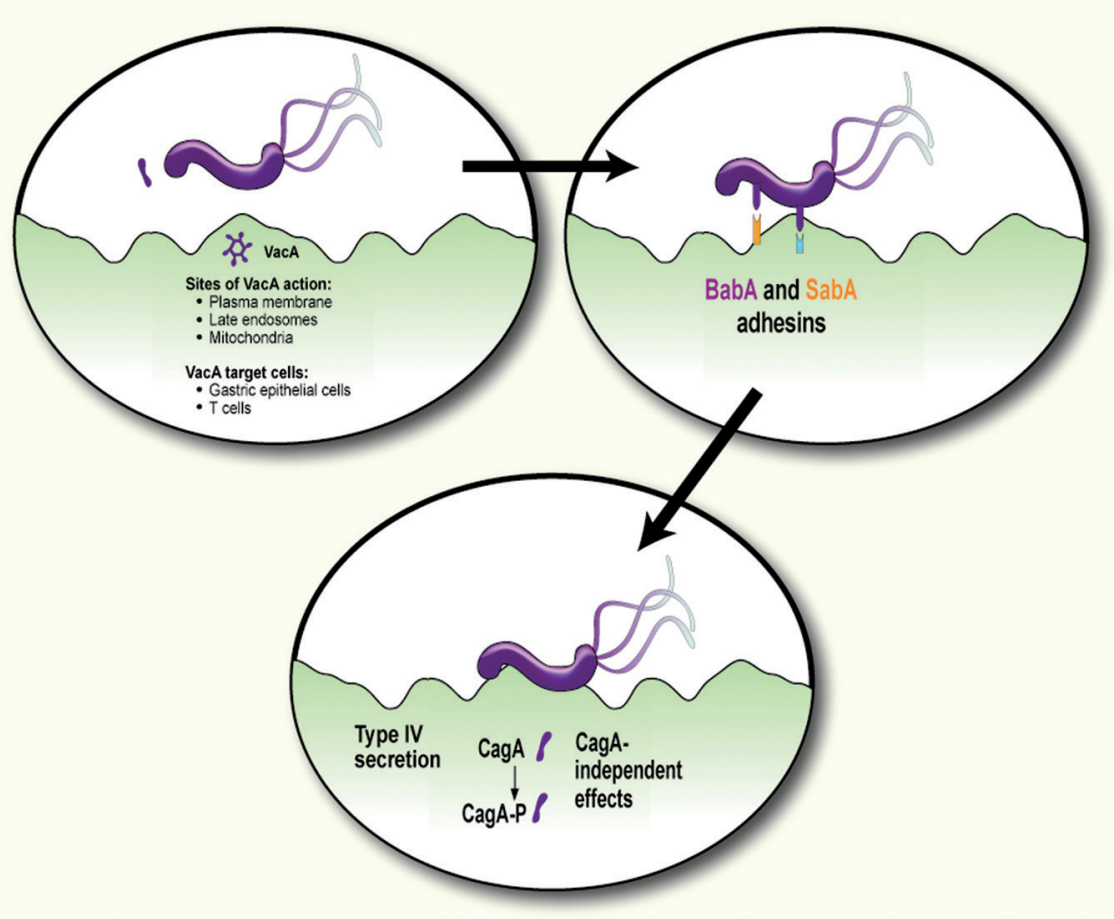

Figure 2. Host-pathogen interacion pattern. ${ }^{21}$ Most of the $H$. Pylori initially localize within the gastric mucus layer but do not directly adhere to gastric epithelial. Different factors especially VacA, released by these non-adherent bacteria, causes alterations in gastric epithelial cells. Besides, BabA and SabA of $H$. Pylori surface mediates crucial interaction with gastric epithelial cells. The cag pathogenicity island of adherent pathogen encode proteins that amalgamate into a secretion apparatus by which CagA factor translocates into the gastric epithelial cells. Inside the gastric cells CagA protein undergoes phosphorylation by host kinases. Both the state of CagA either phosphorylated and nonphosphorylated can triggerextensive cellular alterations.

\section{H. pylori and host microRNA interaction}

Small noncoding RNA known as microRNAs that usually bind 3' un-translated region (UTR) of mRNAs and regulate gene expression by posttranscriptional gene silencing. Variable miRNAs expression frequently found in cancer cells that reveal their functions as either oncogenes or tumor suppressors. In H. pylori-infected host cellsonly one miRNA has been identified as increased expression lavel. ${ }^{26}$ To combat invading pathogens and their secreted effectors host cell utilize Toll-like receptors (TLR) and Nod-like receptors (NLR). ${ }^{27}$ Inside the host celll these receptors subsequently trigger a set of adaptor proteins and transcription factors that finally stimulate host innate immunity through the activation of nuclear factor-jB (NF-jB) and activator protein 1 (AP-1) pathways. Since indecent NF-jB activation trans-activates several target genes harbouring inflammatory, NF-jB would be a prospective molecular connection between inflammation and cancer. $^{28}$

A number of microRNA have been identified as direct and indirect regulator of apoptosis. Among them miR-155 is one of the foremost target of TLR pathway that activated during microbial infection in myeloid cells. Besides, different factors of TLR signaling mechanism including FADD, RIP, and IKK are also down regulated by miR-155. ${ }^{29}$
Conversely, with the up-regulation of miR155, another microRNA miR-125b marked at a decreased lavel. Low expression level of miR-125b allows TNF- $\alpha$ synthesis in the way ofTLR stimulation that has a role in apoptosis. ${ }^{30,31}$ Under noninfectious condition, miR-125b generally repress TNF- $\alpha$ synthesis that ultimately suppress the synthesis of other pro-inflammatory cytokines including TNF- $\alpha$ iself. $^{32}$

miR-146ais also stimulated by NF-jB via TLR2, 4, 5 signaling pathways. In presence of bacterial component, TLR-signaling adaptators IRAK1 and TRAF6 include this miRNA into a negative-feedback loop to control TLR signaling. ${ }^{34,35}$

MiR-21is also induced byactivator protein AP-1 which the signal transducer of transcription factor (STAT3). ${ }^{36,37} \mathrm{H}$. pylori infection induce NF-jB and IL-6 secretion in the gastric epithelial, which first elicit AP-1 followed by the activation of STAT3 pathway.38Another study have showed that miR-21 up-regulation promote cell proliferation, migration and inhibition of apoptosis in the cell line..$^{39}$

MiR-27 an oncogenic miRNA also identified in gastric adeno-carcinoma cell in which it targets prohibitin a tumor suppresor. Prohibitin is an evolutionary conserved and ubiquitous protein of cell-cycle that interact with $\mathrm{pRb}$ and conctrol cell cycle..$^{40,41}$

Role of E2F1 in the up-regulation of micro RNAs, the transition of $1 / \mathrm{S}$ stage of cell cycle 
depends on E2F1 transcriptional factor which sequestered by the unphosphorylated retinoblastoma protein $\mathrm{pRb}$ in resting cell. Although selfly activated E2F1 trans activates a cluster of intronic miRNAs e.g. miR-106b, miR-93 and miR-25 mountedin the $\mathrm{Mcm} 7$ gene which accumulate in gastric primary tumors and gastric epithelial cell lines. ${ }^{42,43}$ Conversely, miR-106b and miR-93 inhibit E2F1 self-activation and supress E2F1expression level through a negative-feedback loop. ${ }^{44}$ In addition to E2F1, p21CIP1/ WAF1 also repressed by miR-106b, miR-93 and miR-25 that leads to the decreased response of gastric cells to TGFb.

miR-106b-25 cluster, locates at chromosome $13 q 31$ and consists genes ofmiR-17, miR-18a, miR-19a, miR-20a, miR-19b-1 and miR-92-1. The cluster of miR-17-92 also identified as the partner of oncogenic potential. In several carcinomas cell like $B$ cell, lung, colon and pancreas miR-17-92 expres- sion lavel found elevated. ${ }^{45,46}$ Moreover, gastric cell also tested as higher expression lavel of miR-17-92 during its cancerous state. ${ }^{47}$ In addition to the miR106b-25 cluster, the miR-221-222 cluster has also increased highly in gastric tumor cell. ${ }^{48}$

microRNA regulation in gastric cancer: Differential expression pattern of miRNAmodulate apoptosis by altering the expression of $\mathrm{Bcl}-2$ family members in gastric tumor (Figure 3). For instance, TGF $\beta$ induce apoptosis in gastric cancer cells through the sequential activation of RUNX3, FoxO3a/ FKHR L1 and finally pro-apoptotic protein Bimand. In this regard, microRNA miR-106b and miR-93 inhibit Bim expression and thus impair TGF $\beta$-induced apoptosis in gastric cancer cells. Moreover, several miRNAs, including miR-15b, miR-16, miR-34 and miR$181 \mathrm{~b}$, have also been shown their interaction with anti-apoptotic protein $\mathrm{Bcl}-2$ and instigate apoptosis. ${ }^{49}$

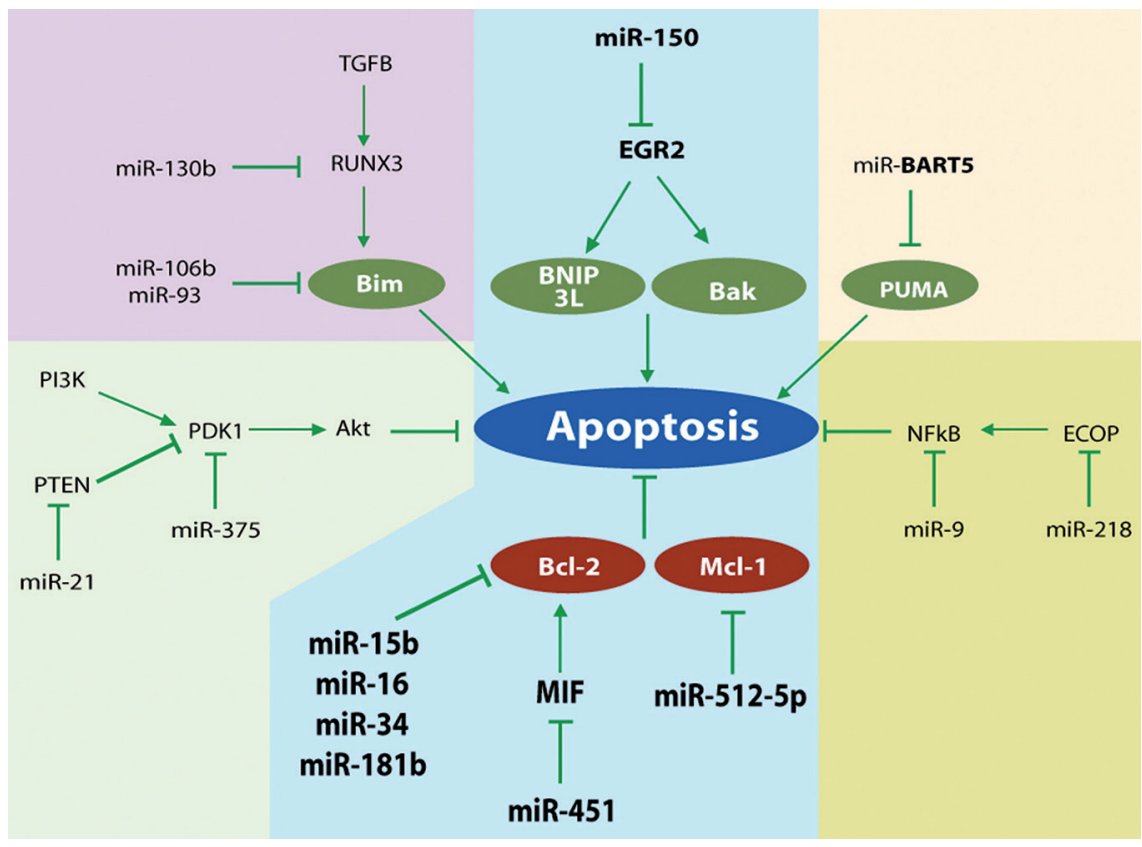

Figure 3. Co-regulation of miRNA and apoptosis in gastric cancer. ${ }^{49}$ Multiple number of miRNAs have been shown to directly or indirectly regulate proapoptotic and anti-apoptotic members of Bcl-2 family. These miRNAs also regulate the PI3k/Akt and NF-kB signaling pathways and exert apoptotic signal that alter the steady state of gastric cancer cells.

\section{Pathogenesis of $\boldsymbol{H}$. pylori infection}

Colonization of $H$. pylori: The ability of $H$. pylori to inhabit the human stomach can be attributed to the assembly of specific toxins or other effectors (Figure 2). One of the bacterial products urease hydrolyzes urea to yield ammonium ions and thereby $H$. Pylori altered to acid resistance. ${ }^{50}$ The motility of flagella enable $H$. pylori to penetrate the gastric mucus layer.
The outer membrane proteins BabA, SabA, AlpA, AlpB, and HopZ, can adhereH. pylori to gastric epithelial cells. Adherence of $H$. pylori to gastric epithelial cells activate a number of signaling pathways ${ }^{51}$ and permits toxins efficient delivery or other effectors into the cells. A number of experiment in an animal model have showed that $H$. Pylori adherence to epithelial cells influences gastric mucosal inflammation, production of auto-antibodies, and parietal cell loss. ${ }^{52}$ 
Earlylmmunomodulation: Altered form of $H$. Pylori lipid A makes its surface LPS less immune sensitive than other negative strain bacterial LPSs. H. pylori flagella are poorly recognized by TLR5 due to the modifications of TLR specific surface antigen. ${ }^{53}$ LPS $\mathrm{O}$ antigens are abundance on numerous $H$. pylori strains which structurally similar to human Lewis blood group antigen. ${ }^{54}$ Thats why, inside the host cell $H$. pylori LPS antigen treated as native..$^{55}$ Besides, modified form of cholesterol on $\mathrm{H}$. pylori surfaceand host plasminogen coating also could resemble as antigenic disguise. ${ }^{56}$ Moreover, several factors also released due to intervation of $\mathrm{H}$. pylori in gastric epithelia that also excites host immune cell. Likewise, H. pylori secreted (VacA) factor stimulate CD4+T cells, inhibiting the transcription factor of $T$ cells proliferation. VacA also restrict $B$ cell antigen presentation and hinder CD8+T, macrophages and mast cells regular function. ${ }^{57}$

There are two other protein arginase and glutamyl transferase expressed in $H$. pylori also alter T cells function. $H$. pylori arginase directly react on macrophages and down-regulates its nitric oxide synthesis ${ }^{58} \mathrm{H}$. pylori generally target host immune cells and strongly causes their down-regulation and thus lenthen its persistence. ${ }^{59}$

Acuteinflammation: The gastric epithelium of $H$. Pylori infected persons has enhanced levels of IL$1 \beta$, IL-2, IL-6, IL-8, and TNFa. Especially, IL8 act as a potent neutrophil activator expressed by gastric epithelial cells, play central role in acute inflamation. ${ }^{60,61}$ It has been validated experimentally that $H$. pylori strains carrying the cag-PAI, provoke a far stronger IL-8 response than cag-negative strains. And the central partners of this IL-8 response are nuclear factor kB (NFkB) and transcription factor activator protein 1 (AP-1). ${ }^{62}$ Moreover another surface protein $(150 \mathrm{kD})$ of $H$. pyloriactivates neutrophil may stimulate phagocytes, though its relation to clinical outcome is still remains indistinct. ${ }^{63}$

Persistent inflammation leads to cancer: All sorts of chronic injury and irritation by infection or no-infection, initiate an inflammatory response. During $H$. pylori infection CagA, get entry into the epithelial cell, induces proliferation and motility signals, as well as production of cytokines. Several mechanisms by which CagA induces the transformational changes in a host cell have been identified, such as its interaction with SHP-2 protein and reaction with cytoplasmic tyrosine phosphatase.$^{64}$

At the injection of CagA into the cell, primarily it phosphorylated by Src family kinases and secondly go interaction with the SHP-2. ${ }^{65}$ Since SHP-2 play an crucial role in regular transduction events, CagA hinder cellular functions by deregulation of SHP-2, inducing cytoskeletal rearrangements, proliferation and increased motility of gastric epithelial cells. Thus CagA-positive $H$. pylori infection up-regulates COX2 expression in gastric mucosa and finally lead to cancer.In resting cell COX-2 is usually absence but at sites of inflamation it becomes abundant and in gastric carcinomas it goes for over expression. ${ }^{66,67}$ This abnormal expression of COX-2 leads to an enhanced genesis of prostaglandins, such as PGE2. Finally, This COX-2 induced prostaglandin pathway accelerate carcinogenesis (Figure 4 ) by modulating cell proliferation, inhibiting apoptosis and by increasing invasiveness of malignant cells.

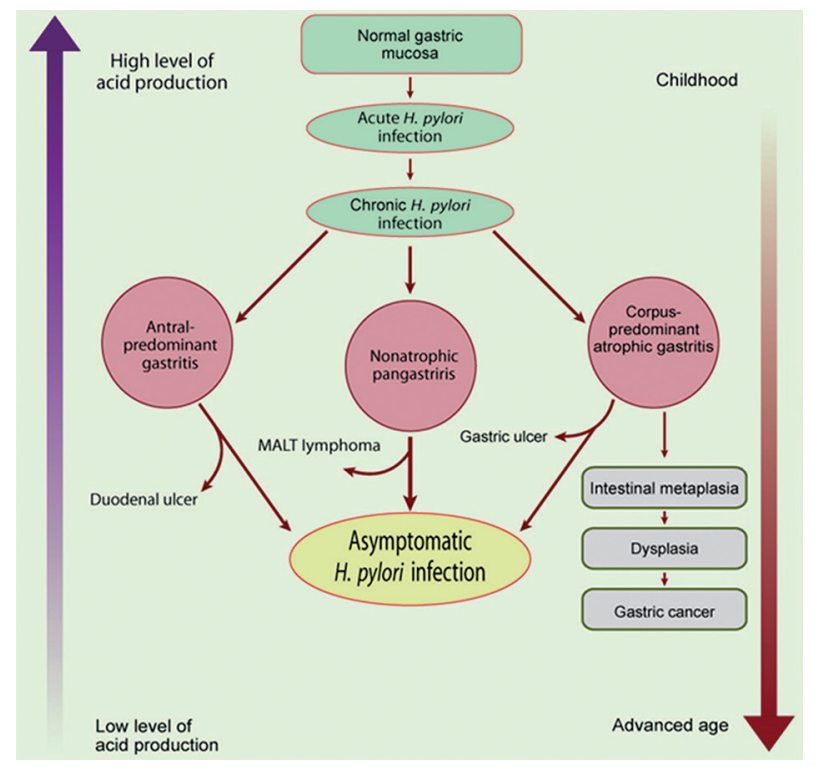

Figure 4. Overview of Helicobacter pylori Pathogenesis. Normally people acquire $H$. pylori in childhood. At acute phase it causes transient hypochlorhydria which is rarely traced by the patients. While colonize persistently in gastric mucosa, it gradually undergoes chronic gastritis without notifying any virtual symptoms. Along with the increment of patient ages, acid production raises steadily and leads to antral-predominant gastritis, which is the major cause of duodenal ulcers. On the other hand, patients with lower acid output for a long period are more likely to have gastritisin in the stomach, which also leads them to gastric ulcer and can initiate a number of sequential events that, in rare cases, could initiate gastric carcinoma. Another rare complication of $H$. pylori infection is the formation of mucosa-associated lymphoid tissue (MALT) which may finally leads to malignant lymphoma. 


\section{CONCLUSION}

$H$. pylori is one of the most common bacterial infections in human, colonizing in the stomach and persist life time in host. Although the human host mounts a vigorous innate and adaptive immune response against the bacterium, but itescapes and evades host responses by a variety of strategy, leading to persistent colonization and chronic active inflammation. Clinical complications of $H$. pylori colonization mainly gastric cancer are therefore likely to represent imbalances in gastric homoeostasis that are unexpected for both microbe and host. Extensive experiment based on interaction between host immune cell and $H$. Pylori could unveil the hidden mechanism of its persistence colonization which could be a new beacon for therapeutic advances.

\section{REFERENCES}

1. Atherton JC. Thepathogenesis of Helicobacter pylori-induced gastro-duodenal diseases. Ann Rev Path 2006; 1: 63-96.

2. Kusters JG, VanAH, Kuipers EJ. Pathogenesis of Helicobacter pylori infection. Clin Microbiol Rev 2006;19: 449-490.

3. Tomb JF, White O, Kerlavage AR. The complete genome sequence of the gastric pathogen Helicobacter pylori. Nature 1997; 388: 539-547.

4. Alm RA, Ling LS, Moir DT. Genomic-sequence comparison of two unrelated isolates of the human gastric pathogen Helicobacter pylori. Nature 1999; 397: 176-180.

5. Falush D, Kraft C, Taylor NS. Recombination and mutation during long-term gastric colonization by Helicobacter pylori: estimates of clock rates, recombination size, and minimal age. Proc Natl Acad Sci U S A 2001; 98:15056-15061.

6. Suerbaum S, Smith JM, Bapumia K. Free recombination within Helicobacter pylori. Proc Natl Acad Sci U S A 1998; 95: 12619-12624.

7. Montecucco C, Papini E, Bernard M. Helicobacter pyloriNacAvacuolatingcytotoxin and HP-Nap neutrophil activating protein. Mol Cell Biol 2001;32:245-263.

8. Rivera CG, Algood HM, Jana N, et al. The intermediate region of Helicobacter pylorivacA is a determinant of toxin potency in a Jurkat T cell assay. Am Soc Microbiol2012; 10: 11281140.

9. Cao P, Cover TL, et al. Two different families of hopQ alleles in Helicobacter pylori. AmSocMicrobiol 2002; 40: 4504-4511.

10. Nestorovich EM, BezrukovSM. Obstructing Toxin Pathways by Targeted Pore Blockage.ChemRev2012;112: 6388-6430.

11. Domanska G, Motz C, Meinecke M, et al.Helicobacter pyIoriNacA Toxin/Subunit p34: Targeting of an Anion Channel to the Inner Mitochondrial Membrane. PLo Patho 2010: 6: 41000878.

12. Jaina $P$, Luob ZQ, Blankea SR.Helicobacter pylorivacuolatingcytotoxin $A(\operatorname{Vac} A$ ) engages the mitochondrial fission machinery to induce host cell death. PNAS 2011; 5: 1105175108.

13. McClain MS, Cao P, Iwamoto $H$, et al.A 12-amino-acid segment, present in type S2 but not type S1 Helicobacter pyloriVacA proteins, abolishescytotoxin activity and alters membrane channel formation. J Bacteriol 2001; 183:6499-6508.
14. Salama NR, Otto G, TompkinsL, Falkow S. Vacuolatingcytotoxin of Helicobacter pyloriplays a role during colonization in a mouse model of infection. Infect Immun 2001; 69: 730-736.

15. Atherton JC, Peek RM, Tham KT, et al.Clinical and pathological importance of heterogeneity in vacA, the vacuolating cy-totoxin gene of Helicobacter pylori.Gastroenter1997; 112:92-101.

16. CensiniS, Lange C, Xiang Z. Cag A pathogenicity island of Helicobacter pylori, encodes type I-specific and disease-associated virulence factors. Proc Natl Acad Sci. U S A 1996; 93: 14648-14653.

17. Odenbreit S, Puls J, Sedlmaier B, et al. Translocation of Helicobacter pyloriCagA into gastric epithelial cells by type IV secretion.Science 2000; 287:1497-500.

18. Higashi H, Tsutsum R, Muto S. SHP-2 tyrosine phosphatase as an intracellular target of Helicobacter pyloriCagA protein. Science 2002; 295: 683-689.

19. Cover TL,BlaserMJ.Helicobacter pylori in health and disease. Gastroenter 2009; 136: 1863-1873.

20. Yokoyama K, Higashi H, Ishikawa S, et al. Functional antagonism between Helicobacter pyloriCagA andvacuolating toxin VacA in control of the NFAT signaling pathway in gastric epithelial cells. Proc Natl Acad Sci U S A 2005;102: 9661-9666.

21. Gerhard M, Lehn N, Neumayer N, et al. Clinical relevance of the Helicobacter pylori gene for blood-group antigenbindingadhesin. Proc Natl Acad Sci U S A 1999; 96: 12778-12783.

22. Atherton JC, Tham KT, Peek RM, et al.Density of Helicobacter pylorinfection in vivo as assessed by quantitative culture and histology. JInfectDis 1996;174:v552-556.

23. Tegtmeyer N, ZableD, Schmidt D, et al.Importance of EGF receptor,HER2/Neu and Erk1/2 kinase signaling for host cell elongation and scattering induced by theHelicobacter pylori CagA protein: antagonistic effects of the vacuolatingcytotoxinVacA. CellMicrobiol 2008; 26: 324-334.

24. Xiao B, Liu Z, Li S, et al.Induction of microRNA-155 during Helicobacter pylori Infection and Its Negative Regulatory Role in the Inflammatory Response. J Infect Dis 2009; 200:916-925

25. Newton K, Dixit VM.Signaling in Innate Immunity and Inflammation.Cold Spring Harbor 2012; 4: 006049.

26. Krishnan J, Basith S, Choi S. Advances in Toll-like Receptor Signaling. Adv Sys Biol 2012; 1: 1 5-15.

27. O'Connell RM, Taganov KD, Boldin MP, et al. MicroRNA-155 is induced duringthe macrophage inflammatory response. Proc Natl Acad Sci USA 2007; 104: 1604-1609.

28. Tili E, MichailleJ, CiminoA. Modulation of miR-155 and miR125b levels followinglipopolysaccharide/TNF-alpha stimulation and their possible roles in regulating the response to endotoxin shock. J Immunol 2006;179: 5082-5089.

29. JiangJ, LeeE, SchmittgenT.Increased expression of microRNA-155inEpstein-Barrvirus transformed lymphoblastoid cell lines. GenChrom Can 2006; 45: 103-106.

30. Volinia S, Calin GA, Liu CG. A microRNA expression signature of human solid tumors defines cancer gene targets. Proc Natl Acad Sci USA 2006;103:2257-2261.

31. CostineanS, ZanesiN, PekarskyY, Pre-Bcellproliferationandlymphoblasticleukemia/high-grade lymphoma in $E(\mathrm{mu})$ miR155 transgenic mice. Proc Natl Acad Sci USA 2006; 103: 7024-7029.

32. Belair C, Darfeuille F, Staedel C. Helicobacter pylori and gastric cancer: possible role of microRNAs in this intimate relationship. Clin Microbiol Infect, 2009; 15:806-812 
33. Tili E, Michaille J, Cimino A. Modulation of miR-155 and miR$125 \mathrm{~b}$ levels following lipopolysaccharide/TNF-alpha stimulation and their possible roles in regulating the response to endotoxin shock. J Immunol 2007; 179: 5082-5091.

34. Karin M, Lawrence T, Nizet V. Innate immunity gone awry: linking microbial infections to chronic inflammation and cancer. Cell 2006; 124: 823-835.

35. Fujita S, ItoT, Mizutani T. miR-21GeneexpressiontriggeredbyAP-1 issustainedthrougha double-negative feedback mechanism. J Mol Biol 2008;378:492-504.

36. LofflerD, Brocke Heidrich K, Pfeifer G. Interleukin-6dependentsurvivalofmultiple myeloma cells involves the Stat3-mediated induction of microRNA-21 through a highly conserved enhancer. Blood 2007; 110: 1330-1333.

37. ZhangZ, LiZ, GaoC. miR-21 play pivotal role in gastric cancer pathogenesis and progression. Lab Invest 2008;88: 13581366.

38. LiuT, TangH, LangY, et al. MicroRNA-27afunctionsasanoncogeneingastric adenocarcinoma by targeting prohibitin. Cancer Lett 2005; 273: 233-242.

39. Mertens SU, Chintharlapalli S, Li X, et al.The oncogenic microRNA-27a targets genes that regulate specificity protein transcription factors and the G2-M checkpoint in MDAMB-231 breast cancer cells. Cancer Res 2007;67: 1100111011.

40. Petrocca F, Visone R, Onelli MR. E2F1-regulated microRNAs impair TGFbeta-dependent cell-cycle arrest and apoptosis in gastric cancer. Cancer Cell 2008; 13: 272-286.

41. Petrocca $F$, Vecchione A, Croce CM. Emerging role of miR106b-25/miR-17-92 clusters in the control of transforming growth factor beta signaling. Cancer Res 2006; 68: 81918194.

42. Petrocca F, Visone R, Rapazzotti M, et al. miR-106b and miR-93 decrease E2F1 expression, establish-ing a negative-feedback loop preventing E2F1 self-activation. Cancer Cell2008; 133: 272-286.

43. He L, Thomson JM, Hemann MT. AmicroRNA polycistron as a potential human oncogene. Nature 2005; 435:828-833.

44. Volinia S, Calin GA, Liu CG. A microRNA expression signature of human solid tumors defines cancer gene targets. Proc Natl Acad Sci USA 2006; 103: 2257-2261.

45. Xiao C, Srinivasan L, Calado DP. Lymphoproliferative disease and autoimmunity in mice with increased miR-17-92 expression in lymphocytes. Nat Immunol 2008;9: 405-414.

46. Kim Y, Yu J, Han T. Functional links between clustered microRNAs: suppression of cell-cycle inhibitors by microRNA clusters in gastric cancer. Nucl Ac Res 2009; 67: 367-373

47. Wu W, Lee $\mathrm{CW}$, Cho $\mathrm{CH}$, et al.MicroRNA dysregulation in gastric cancer: a new player enters the game. Oncogen2010; 352: 1-11.

48. Marshall BJ, Barrett C, Prakash R, et al.Urea protects Helicobacter (Campylobacter) pylori from the bactericidal effect of acid. Gastroent 1990; 99:697-702.

49. Guillemin K, Noor R, Salama LS, Tompkins SF. Cagpathogenicity island-specific responses of gastric epithelial cells to Helicobacter pylori infection. Proc Natl Acad Sci USA 2002; 99:15136-15141.

50. Guruge JL, Falk PG, Lorenz M, et al.Epithelial attachment alters the out-come of Helicobacter pylori infection. Proc Natl Acad Sci USA 1998; 95:3925-3930.
51. Takeda K, Soon A.Toll receptors and pathogen resistance. CellMicrobiol 2003; 5:143-153.

52. Aspinall GO, Monteiro MA. Lipopolysaccharides of Helicobacter pylori strains P466 and MO19: structures of the O antigen and core oligosaccharide regions. Biochem 1996; 35: 2498-2504.

53. Jonsson K, Guo BP, Monstein HJ, Mekalanos JJ. Molecular cloning and characterization of two Helicobacter pylori genes coding for plasminogen-binding proteins.ProcNatl Acad Sci USA 2004; 101:1852-1858.

54. Wunder C, Churin Y, Winau F, et al.Cholesterol glucosylation promotes immune evasion by Helicobacter pylori. Nat Med 2006;12:1030-1038.

55. Algood HM, Torres D, UnutmazTL. Resistance ofprimary murine CD4+ T cells to Helicobacter pylorivacuolatingcytotoxin Infect Immun 2007; 75:334-341.

56. Zabaleta J, McGee AH, Zea CP, et al.Helicobacter pyloriarginase inhibits $\mathrm{T}$ cell proliferation and reduces the expression of the TCR zeta-chain (CD3). J Immunol 2004; 173:586-593.

57. Wunder C, Churin Y, Winau F. Cholesterol glucosylation promotes immune evasion by Helicobacter pylori. Nat Med 2006; 12:1030-1038.

58. Fox JG, Beck CA, Dangler MT, et al.Concurrent enteric helminth infection modu-lates inflammation and gastric immune responses and reduces Helicobacter induced gastric atrophy. Nat Med 2000; 6:536-542.

59. Harris PR, Smythies LE, Smith PD, Dubois A. Inflammatory cytokinemRNA expression during early and persistent Helicobacter pylori infectionin nonhuman primates. J Infect Dis 2000; 181: 783-789.

60. Fischer W, Puo L, Buhrdorf R, et al. Systematic mutagenesis of the Helicobacter pylori cag pathogenicity island: essential genes for CagA translocation in host cells and induction of interleukin-8. Mol Microbiol 2001; 42:1337-1348.

61. Naumann M, Wessler S, Bartsch C. Activation of activator protein 1 and stress response kinases in epithelial cells colonized by Helicobacterpylori encoding the cag pathogenicity island. J Biol Chem 1999; 274:31655-31662.

62. Higashi H, Tsutsumi R, Muto S, et al.SHP-2 tyrosine phosphatase as an intracellular target of Helicobacter pyloriCagA protein.Science2002; 295: 683-686.

63. Higashi H, Nakaya A, Tsutsumi R, et al.Helicobacter pyloriCagA inducesRas-independent morphogenetic response through SHP-2 recruitment and activation. J BiolChem2004; 279:17205-17216.

64. Yamac D, AyyildizT, Coskun U. Cyclooxygenase-2 expression and its association with angiogenesis, Helicobacter pylori, and clinicopathologic characteristics of gastric carcinoma.Pathol ResPract 2008; 204: 527-536.

65. Li Q, Liu N, Shen B. Helicobacter pylori enhances cyclooxygenase 2 expression via p38MAPK/ATF-2 signaling pathway in MKB45 cells. Cancer Lett 2009; 278:97-103.

66. Yamac D, Ayyildiz T, Coşkun U, et al. Cyclooxygenase-2 expression and its association with angiogenesis, Helicobacter pylori, and clinicopathologic characteristics of gastric carcinoma.PatholResPract 2004;204: 527-536.

67. Suerbaum S, Michetti P. Helicobacter pylori infection. N Engl J Med 2002; 347: 151175-1186. 